\title{
The Effectiveness of Science Textbook Based on Science Technology Society for Elementary School Level
}

\author{
Aliffah Kartikasari ${ }^{1}$, Roemintoyo ${ }^{2}$, Sri Yamtinah ${ }^{3}$ \\ ${ }^{1}$ Master Program of Elementary School Teacher Training and Education, Sebelas Maret University, Indonesia \\ ${ }^{2,3}$ Postgraduate Department, Sebelas Maret University, Indonesia
}

\begin{tabular}{l} 
Article Info \\
\hline Article history: \\
Received Apr 30, 2018 \\
Revised May 27, 2018 \\
Accepted May 30, 2018 \\
\hline
\end{tabular}

\section{Keyword:}

Elementary school

Science technology society

Science textbook

\begin{abstract}
This study reported a quasi-experimental investigating the development of Science textbook based on Science Technology and Society for elementary school. The study employed quasi experiment design. Population in this study was all fourth-grade students of elementary schools in Gatak Subdistrict and the sample of the study was two schools as an experimental class and control class. The research sample was taken by random sampling technique. The results of this research showed that there was an improvement of student achievement before and after the implementation of science textbook based on Science Technology and Society. The study concluded that the development of a science textbook based on Science Technology Society in elementary school is appropriate to use for learning.
\end{abstract}

Copyright (C) 2018 Institute of Advanced Engineering and Science. All rights reserved.

\section{Corresponding Author:}

Aliffah Kartikasari

Department of Elemtary School Teacher Training and Education,

Sebelas Maret University,

J1. Ir. Sutami No. 36A, Jebres, Surakarta, Jawa Tengah, Indonesia ,57126.

Email: aliffah.ak@gmail.com

\section{INTRODUCTION}

Education is a very important part to develop the ability and character of a nation based on the goals and ideals to be achieved by the nation. Education is useful for developing students' intelligence, which consists of intellectual, spiritual, emotional, social, and kinesthetic intelligence. Thus education can build human, that human human. To respond to global challenges, Indonesians need to have high-level thinking skills, which can be realized with science education. Science education can be realized through various efforts, one of them with science learning. Science learning has tremendous potential in building the nation. Scientifically literate person understand and be aware of needs of the community to be able to participate technological oriented economy [1]. Science, technology, and society (STS) was a term indicating reform teaching to provide these needs [2].

Science is one of the required subjects in Indonesian education curriculum, especially for elementary school level. Learning science in elementary school level is aimed to inculcate the basic concepts of learning science so that it is beneficial for students to solve the problems in the future. The objective of education is not only to obtain cognitive value but also to create an educational culture that inculcates understanding and problem-solving. To achieve these objectives, the appropriate teaching materials are required so that students can master the competencies. The material development guidelines explain that developing teaching materials should consider the demands of the curriculum. It means that the developing teaching materials must be in accordance with the implementation of the curriculum [3].

Based on 2013 Curriculum, the teaching materials consists of teacher's book and student's textbook. The core and basic competencies have had been arranged by the government so that all schools can achieve the same results at the end of each competency. Thus, the developing of teaching materials should refer to the 
curriculum. In this case, teaching material is textbook. Textbooks are books containing materials that have been selected in particular field of science, systematically organized to support teaching and learning process [4]. A good textbook should be arranged systematically and easy-to-understand for students. Too many visual displays can make difficult for students to understand the concept of science [5]. The development of textbooks is expected to fulfill the need of conceptual knowledge, identifying misunderstandings, and designing teaching materials [6].

The developing of textbook should be based on the student needs Based on the interviews with teachers, it was revealed that the textbook lack of material. The existing textbook, teacher's and student's books have been integrated with several other subjects. In fact, the content of science textbook is depthless. It can be seen from the content of the material of the students' book. Most of the contents are in the form of student performance and discussion sheet which leads to lack of inculcating the basic concept of science. One teacher revealed that the presentation of the 2013 curriculum textbook is already good and student center oriented that aims to make students active during the learning. However, the lack of material causes students having less the basic concepts of learning science. Therefore, it is necessary to have a supplement textbook that is used as a companion book to overcome the problem.

The development of science textbook based on Science Technology Society can improve students' understanding of science concept [7]. Science Technology Society uses daily community issues to improve students' ability in solving the problems [8]. Thus, learning science based on Science Technology Society can be used to develop critical and scientific thinking and become technologically literate citizens [9].

In this research, the development of science textbooks based on science technology society is arranged based on the student's problems environment. The problem is simple, such as how to maintain the school environment. Thus, students can simply solve the problems. The results presented in this study are the implementation of science technology society based textbooks in the learning process.

\section{RESEARCH METHOD}

The textbooks developed in this experiment have been validated by several experts, consisting of Science materials experts, linguists, and design experts. The validator consists of lecturers and practitioners, who are experienced primary school teachers. Ranking criteria is: $4=$ very good, $3=$ good, $2=$ less good, $1=$ not good. Expert material expert validation results can be seen in Table 1.

Table 1. Results of Expert Textbook Validation

\begin{tabular}{ccccc}
\hline Component & $\begin{array}{c}\text { Description of Science Textbook Based on } \\
\text { Science Technology Society }\end{array}$ & \multicolumn{2}{c}{ Validator Result } & Average \\
& & Lecturer & Practitioner \\
\hline Materials & Subtance of science materials & 3.88 & 3.84 & 3.86 \\
& Application of science technology society in & 3.78 & 3.80 & 3.79 \\
textbook & Language assignment & 3.87 & 3.88 & 3.87 \\
Language & The use of communicative language & 3.86 & 3.84 & 3.85 \\
& Book cover design & 3.87 & 3.82 & 3.85 \\
& Design the content of the book & 3.78 & 3.70 & 3.74 \\
\hline
\end{tabular}

This study was a quasi-experimental study using pretest-posttest control group design [10]. The study design was to compare experimental and control groups. The experimental group is a group given the treatment of textbooks based on science technology society, while the control group is a group taught by the existing textbook. The research design can be seen in Table 2.

Table 2. Research design

\begin{tabular}{cccc}
\hline Group & \multicolumn{3}{c}{ Research Activity } \\
\hline Experimental group $(\mathrm{N}=20)$ & $\mathrm{O}_{1}$ & $\mathrm{X}_{1}$ & $\mathrm{O}_{2}$ \\
Control group $(\mathrm{N}=20)$ & $\mathrm{O}_{1}$ & $\mathrm{X}_{2}$ & $\mathrm{O}_{2}$ \\
\hline
\end{tabular}

$\mathrm{O}_{1} \quad$ : Pretest

$\mathrm{O}_{2} \quad$ : Posttest

$\mathrm{X}_{1} \quad$ : Treatment using science textbook based on Science Technology Society

$\mathrm{X}_{2} \quad$ : using the existing textbook 
The data were collected from the pretest and posttest score, both experimental and control group. Besides, the instrument used 25 multiple questions. Then, two steps analyses were used to analysis the data. First, independent sample t-test employed to calculate the significant difference of posttest score. Having known that the treatment was given significant effect on the improving students' learning science outcomes, then the next step was to measure the improvement between before and after treatment. The improvement result was calculated using the Normalized Gain (N-Gain) [11].

The criteria used in N-Gain are guided by the assessment standards which described in Table 3 [12]. Table 3 shows that if $\mathrm{N}$-Gain score is less than 0.3 , it belongs to low, if the score is between 0.3-0.7 belongs to medium, and if it is more than 0.7 belongs to high category. Science textbooks based on Science Technology Society can be said improve science learning outcomes if N-Gain score reaches at least medium category.

Table 3. N-Gain Score Criteria

\begin{tabular}{cc}
\hline N-Gain & Categori \\
\hline $\mathrm{g}<0.3$ & Low \\
$0.7>\mathrm{g} \geq 0.3$ & Medium \\
$\mathrm{g} \geq 0.7$ & High \\
\hline
\end{tabular}

\section{RESULTS AND ANALYSIS}

Pretest and posttest score from both experimental and control group can be seen in Table 4.

Table 4. Pretest and posttest score from experimental and control group

\begin{tabular}{ccccc}
\hline Class Group & Score & Minimum Score & Maximum Score & Mean \\
\hline Treatment & Pretest & 36 & 88 & 61.71 \\
& Posttest & 60 & 92 & 76.38 \\
\multirow{3}{*}{ Control } & Pretest & 36 & 80 & 52 \\
& Posttest & 44 & 84 & 60.54 \\
\hline
\end{tabular}

The method used to get the mean difference is the independent sample t-test. The significance level of effectiveness test alpha is 0.05 . Decision-making of test results by comparing the tcount and ttable values and comparing the significance value used SPSS software with alpha output. The test results of independent sample t-test can be seen in Table 5 .

Table 5. Independent sample t-test result

\begin{tabular}{cccccc}
\hline Experimental & Control & $\mathrm{t}_{\text {obs. }}$ & $\mathrm{t}_{\text {table }}$ & Sign. & alpha \\
\hline 76.381 & 60.545 & 5.489 & 1.681 & 0.000 & 0.05 \\
\hline
\end{tabular}

Based on Table 5, it can be seen that the average posttest experimental group is 76.381 while the mean posttest control group is 60.545 . This means that the mean of the experimental group posttest is higher than the control group. Results of the $t$ test using independent sample t-test obtained t-count 5,489 which is greater than t-table (1.681). Having seen from the significance level of t-test, the level of significance is lower than $\alpha(0.000<0.05)$. The next step is to compare the mean of posttest experimental group and the control group. Based on Table 3, it can be seen that the mean of posttest experimental group is higher than the control group $(76.381>60.545)$. To find out how the improvement difference both groups, N-Gain test was done. The result of $\mathrm{N}$ gain test can be observed in Table 6 .

Tabel 6. The analysis of N-Gain Average Improvement

\begin{tabular}{ccc}
\hline Average & Eksperimental group & Control group \\
\hline Pretest & 61.71 & 52 \\
Posttest & 76.38 & 60.54 \\
N-Gain & 0.558 & 0.266 \\
\hline
\end{tabular}


From Table 6, it is revealed that there is improvement from pretest and posttest score in both experimental and control group. Meanwhile, the improvement of experimental group is more significant than control group. As written in the table, the experimental group gets 0.558 while control group gets 0.266 . It can be proofed that the implementation of Science Technology Society based textbook is more effective than the existing textbook.

The use of teaching modules to improve student achievement should be widely used in various levels of educational classes [13]. Teachers should develop methods that match the books used [14]. By using science technology society methods in the learning process, it can increase students' ability in solving problems. The interaction among action, participation, and conceptualization becomes the instrument in the development of learning science [15]. Based on Table 3, the score which obtained by the experimental group is higher than the control group. This shows that the use of science technology community technology based textbook more is effective to improve student learning outcomes. The changes in the textbook make students more interested in studying science and help students to relate learning science with daily life. With these changes, it can improve students' understanding and learning outcomes [16].

The use of Science Technology Society encourages teachers to use a more explicit methodology than traditional class-oriented textbooks. Thus the students have the opportunity to investigate the problems that exist in everyday life [17]. In classroom-oriented traditional textbooks, teachers use more implicit teaching methodologies. They became the course director instead of being a facilitator. Teachers only focus on textbooks and have no flexibility during the course. Students working on a given problem have no relation to student life or local social issues [18]. In applying STS learning, teachers should have special skills in education programs [19].

The use of science technology society based textbook can improve the students' attitudes becoming more positive in learning science. The attitudes are at the time of learning and attitudes toward teachers. Students who are taught using science technology society are more capable to master the concepts than students who are taught using conventional way. So, the science-process skills acquired are even higher [20]. Science Technology Society has several advantages, such as broaden students' knowledge in learning science as well as learning more effectively, making students aware of the problems, helping students to make joyful learning; so, it can change the paradigms and thoughts in learning science over the years [21].

\section{CONCLUSION}

Based on the results and hypotheses that have been determined, it can be concluded that Textbookbased Science Technology Society is more effective to improve student learning outcomes. The statistical analysis result shows a significant difference between the posttest control groups that uses the existing textbook with the class that uses textbook-based discovery learning.

\section{ACKNOWLEDGEMENTS}

Acknowledgment are given to all those who have helped in the writing of this scientific article, especially to the mentors who never get tired to guide and give input and feedback to the researchers.

\section{REFERENCES}

[1] Sofowora, O.A. \& Adekomi, B. 2012. Improving science, technology and mathematics education in Nigeria: A case study of Obafemi Awolowo University, Ile-Ife. African Journal of Educational Studies in Mathematics and Sciences, 10,1-8.

[2] Driver, R., Leach, J., Miller, R., \& Scott, P. 2000. Young people's images of science. Buckingham: Open University Press.

[3] Depdiknas. 2008. Guidance on the development of teaching materials. Directorate General of Management of Primary and Secondary Education.

[4] Muslich, Masnur. 2015. Text Book Writing. Yogyakarta: Ar-Ruzz Media.

[5] Cook, M. 2008. Students' comprehension of science concepts depicted in textbook illustrations. Electronic Journal of Science Education, 12(1), 1-14.

[6] G M Sinatra and S H Broughton. 2011. Bridging Reading Comprehension and Conceptual Change in Science Education: The Promise of Refutation Text Read. Res. Q. Int. Read. Assoc. 46 (4)

[7] Binadja, A. 2006. Guidelines for the Development of a SABS Syllabus and Approach (Science, Environment, Technology and Society) or (Science, Environment, Technology and Society) Learning Materials Special Issuance of MIPA Media UNNES. Semarang: SETS Laboratory. Semarang State University.

[8] Suyatna, A., \& Anggraini, D. 2017. Efforts to Handle Waste through Science, Environment, Technology and Society ( SETS ) Efforts to Handle Waste through Science, Environment, Technology and Society (SETS).

[9] Pedretti 2003 Teaching Science, Technology, Society and Environment (STSE) Education

IJERE Vol. 7, No. 2, June 2018 : 127 - 131 
[10] Cresswell, J. W. 2008. Planning, Conducting, and Evaluating Quantitative and qualitative research Fourth ed. Boston: Pearson Education.

[11] Meltzer, D. E. 2002. The Relationship between Mathematics Preparation and Conceptual Learning Gains in Physics: a Possible Hidden Variable in Diagnostic Pretest Scores, American Journal on Physics, vol. 70, pp. 12591268.

[12] Hake, R. R. 1998. Interactive-Engagement vs Traditional Methods: A Six-Thousand-student Survey of Mechanics Test Data for Introductory Physics Courses. American Journal on Physics, vol. 66, pp. 64-74.

[13] Kulldel, N. 2007. Authentic Teaching and Learning through Synthetic Biology. Journal of Biological Engineering Vol.1 (8), 1-6.

[14] Andersson, B. 2000. National evaluation for the improvement of science teaching. In R. Millar, J. Leach, \& J. Osborne (Eds.), Improving science education: The contribution of research (pp. 62-78). Birmingham, UK: Open University Press.

[15] Tal, R. T., Dori, Y. J., Keiny, S., \& Zoller, U. 2001. Assessing conceptual change of techers involved in STES education and curriculum devleopment - The STEMS project approach. International Journal of Science Education, 23(3), 247-262.

[16] Abualrob, M. M. A., \& Daniel, E. G. S. 2013. The Delphi Technique in Identifying Learning Objectives for the Development of Science, Technology and Society Modules for Palestinian Ninth Grade Science Curriculum. International Journal of Science Education, 35(15), 2538-2558.

[17] Akcay, H., Yager, R. E., Iskander, S. M., \& Turgut, H. 2010. Change in student beliefs about attitudes toward science in grades 6-9. Asia-Pacific Forum on Science Learning and Teaching, 11(1), 1-18.

[18] Singh, A., Yager, S. O., Yutakom, N., Yager, R. E. \& Ali, M. M. 2012. Constructivist teaching practices used by five teacher leaders for the Iowa chautauqua professional development program. International Journal of Environmental \& Science Education, 7(2), 197-216.

[19] Tsai, C. C. (2006). Reinterpreting and reconstructing science: teachers' view changes toward the nature of science by courses of science education. Teaching and Teacher Education, 22, 363-375.

[20] Akcay, H., \& Yager, R. E. 2010. The impact of a Science/Technology/Society teaching approach on student learning in five domains. Journal of Science Education and Technology, 19(6), 602-611.

[21] Dass, P. M 2005 Using a Science Technology Society Approach To Prepare Reform-Oriented Science Teachers: The Case of a Secondary Science Methods Course. Issues in Teacher Education, 14(1), 95-108

\section{BIOGRAPHIES OF AUTHORS}

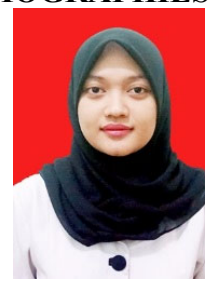

Aliffah Kartikasari graduated from Elementary School teacher Training and Education at Sebelas Maret Unversity in 2015. Currently, she is studying at the same department for master degree at Sebelas Maret University. Her research interest is create textbooks for elementary school students.

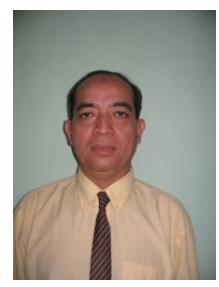

Roemintoyo is a doctor of education management. He also teaching in Elementary School teacher Training and Education at Sebelas Maret Unversity. The field he mastered was the management of education. He has published widely in various referred journal.

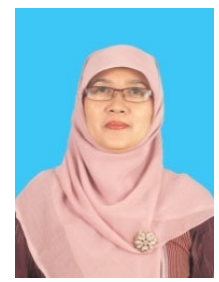

Sri Yamtinah is a doctor of education evaluation. She is also teaching in Elementary School teacher Training and Education at Sebelas Maret Unversity. She is master in the field of educational evaluation. She has published widely in various referred journal and presented paper in national and international conferences. 